\title{
Seven new species of Resartor Gustafsson et Bush, 2017 (Phthiraptera: Ischnocera: Philopteridae) from Asian 'babblers' (Passeriformes: Leiothrichidae, Paradoxornithidae)
}

\author{
Daniel Roland Gustafsson ${ }^{1}$, Xingzhi Chu ${ }^{1}$, Sarah Elizabeth Bush ${ }^{2}$, Fasheng Zou ${ }^{1}$ \\ ${ }^{1}$ Guangdong Key Laboratory of Animal Conservation and Resource Utilization, Guangdong Public Laboratory of Wild Animal \\ Conservation and Utilization, Guangdong Institute of Applied Biological Resources, Guangzhou, Guangdong, China; \\ ${ }^{2}$ Department of Biology, University of Utah, Salt Lake City, Utah, USA
}

\begin{abstract}
Seven new species of chewing lice in the genus Resartor Gustafsson et Bush, 2017 are described and illustrated. They are: Resartor albofulvus sp. n. ex Heterophasia desgodinsi desgodinsi (Oustalet); Resartor apimimus sp. n. ex Heterophasia picaoides wrayi (Ogilvie-Grant); Resartor aterrimus sp. n. ex Minla ignotincta mariae La Touche; Resartor extraneus sp. n. ex Lioparus chrysotis swinhoii (Verreaux); Resartor guangxiensis sp. n. ex Trochalopteron milnei sinianum Stresemann; Resartor longisuturalis sp. n. ex Actinodura cyanouroptera wingatei (Ogilvie-Grant); Resartor seminudus sp. n. ex Leiothrix argentauris tahanensis (Yen). All species differ in the shape of the head, shape of the male genitalia and abdominal chaetotaxy. A checklist and a key to the species of Resartor are provided.
\end{abstract}

Keywords: Brueelia-complex, China, Malaysia, species description, morphology

'Babblers' are a group of related bird species from several families that occur across South Asia and Africa. The taxonomy of this group is in flux, and several species previously thought to belong in this radiation have been moved to more distantly related families (Cibois et al. 1999, 2001, Reddy and Cracraft 2007, Oliveros et al. 2012, Alström et al. 2014). The majority of the species previously considered 'babblers' are placed in one of five closely related families (Leiothrichidae, Paradoxornithidae, Pellorneidae, Timaliidae, Zosteropidae - Gelang et al. 2008, Moyle et al. 2009, 2012, Yeung et al. 2011). Collectively, these families are closely related to the warbler family Sylviidae (Moyle et al. 2012).

To date, 76 species of chewing lice are known from babblers (Price et al. 2003, 2006, Najer et al. 2012, Gustafsson and Bush 2017, Mey 2017, Gustafsson et al. 2018). Amblyceran lice of the genus Myrsidea Waterston, 1915 have been described from several hosts of the Leiothrichidae and from one host species each in the Pellorneidae and Timaliidae (Ansari 1951, Tandan and Clay 1971, Tandan 1972, Rai 1978, Price et al. 2006, Najer et al. 2012). Material from additional host species in the Leiothrichidae, Pellorneidae and Timaliidae has been reported but not described (Najer et al. 2012, 2014).
Species of lice belonging to the Brueelia-complex have been described from members of Leiothrichidae, Paradoxornithiidae, Pellorneidae and Timaliidae (Ansari 1947, 1955, 1956, Eichler 1957, Najer et al. 2012, 2014, Gustafsson and Bush 2017, Mey 2017, Gustafsson et al. 2018). Gustafsson and Bush (2017) revised the Brueelia-complex, and divided the species known from babblers into six genera: Brueelia sensu stricto Kéler, 1936 (= Painjunirmus Ansari, 1947), Guimaraesiella Eichler, 1949, Ceratocista Gustafsson et Bush, 2017, Resartor Gustafsson et Bush, 2017, Turdinirmoides Gustafsson et Bush, 2017, and Priceiella Gustafsson et Bush, 2017. Mey (2017) described additional genera, all of which are synonymous with those proposed by Gustafsson and Bush (2017) except Timaliinirmus Mey, 2017, which includes a single species placed in Turdinirmoides by Gustafsson and Bush (2017).

The distribution of louse species of the Brueelia-complex lice on the different babbler families and genera is poorly known. Species of the genus Guimaraesiella infest a broad array of hosts including babblers, but the species of this genus occurring on babblers are not known from non-babbler hosts (Gustafsson and Bush 2017, Gustafsson et al. 2019 in press). Moreover, all species of the three Brueelia-complex genera Ceratocista, Resartor and Timaliinirmus are entirely restricted to babbler hosts. In addition,

Address for correspondence: Daniel Gustafsson or Fasheng Zou, Guangdong Key Laboratory of Animal Conservation and Resources, Guangdong Public Laboratory of Wild Animal Conservation and Utilization, Guangdong Institute of Applied Biological Resources, Xingang West Road 105, Haizhu district, Guangzhou, 510260, China. Phone: +86-1392-6056291. Email: kotatsu@fripost.org or zoufs@gdei.gd.cn.

Zoobank number for article: urn:lsid:zoobank.org:pub:479C1AFE-C31A-46E3-8281-078A46480799 
the species of Brueelia occurring on babblers of the genus Turdoides Cretzschmar, are known only from babblers; the generic name Painjunirmus has been proposed for this group, which is morphologically very distinct. Only one of the 33 species of Priceiella occurs on a non-babbler host species (Gustafsson and Bush 2017). Molecular data indicate that Brueelia-complex lice from babblers do not form a monophyletic clade (Bush et al. 2016), and morphological differences among these louse genera support this assertion (Gustafsson and Bush 2017). These data suggest that host switching has played an important role in the distribution and diversification of babbler lice. A more rigourous understanding of chewing louse diversity on babblers and their evolutionary and co-evolutionary history is hampered by the low number of described species from these hosts.

In this study, we describe seven new species of Resartor. Six of them are associated with bird genera not previously recorded as hosts of Resartor, and one species is the first Resartor known from a host outside the Leiothrichidae. These new records extend the number of bird genera with species hosting species of Resartor from two to seven, as follows: Actinodura Gould; Grammatoptila Reichenbach; Heterophasia Blyth; Leiothrix Swainson; Lioparus Oates; Minla Hodgson; and Trochalopteron Blyth.

\section{MATERIAL AND METHODS}

Holotypes of the new species described herein are deposited in the Natural History Museum, London, United Kingdom (NHML), the Oklahoma State University, Stillwater, Oklahoma, United States of America (OSUS), the Price Institute for Parasite Research, University of Utah, Salt Lake City, Utah, United States of America (PIPeR), or the Guangdong Institute for Applied Biological Resources, Guangzhou, Guangdong, China (GIABR). All examined material was mounted in Canada balsam on microscope slides. Specimens were examined and measured with a Nikon Eclipse E600 fitted with an Olympus DP25 camera, and digital measuring software (ImageJ, 1.48v, Wayne Rasband). Illustrations were prepared using a drawing tube fitted to the microscope, and edited in GIMP (www.gimp.org). Specimens from type hosts are illustrated unless otherwise noted. Host taxonomy follows Clements et al. (2017).

Terminology of setal, structural, and genital characters, and the associated abbreviations, follow Gustafsson and Bush (2017). These include: $a d s$ - anterior dorsal seta; $d s m s$ - dorsal submarginal seta; $m t s 3$ - marginal temporal seta 3; pmes - posterior mesosomal setae; $p s$ - pleural seta; psps - principal postspiracular seta; $p s t$ - parameral setae; tps - tergal posterior seta; $v m s$ - vulval marginal setae; vos - vulval oblique setae; vss - vulval submarginal setae. Measurements are given in millimetres for the following dimensions: TL - total length (along midline); HL head length (along midline); HW - head width (at temples); PRW - prothoracic width; PTW - pterothoracic width; AW - abdominal width. Ranges of each of these dimensions are given; mean dimensions are also provided in parentheses for measurements with ten or more lice measured.

In the illustrations, narrow lines on tergopleurites indicate approximate extent of the dark pigmentation along the lateral margins of the abdomen of all species. Distal parts of legs are not illustrated. In a few cases, distal parameres were everted in all examined males, and their exact shape therefore could not be illustrated accurately; therefore, the approximate shapes of these structures are illustrated by dotted lines. The anterior ends of the genitalic basal apodemes of some species are also illustrated with dotted lice because their true shapes were obscured by gut content, or these sections of the apodemes were translucent in all examined males of the species.

\section{RESULT}

Phthiraptera Haeckel, 1896

Ischnocera Kellog, 1896

Philopteridae Burmeister, 1838

Brueelia-complex

Resartor Gustafsson et Bush, 2017

Brueelia Kéler, 1936: 257 (in partim).

Resartor Gustafsson et Bush, 2017: 104.

Leiothrichinirmus Mey, 2017: 166.

Type s pecies: Brueelia impressifrons Ansari, 1956: 152, by original designation.

Comments: Gustafsson and Bush (2017) based their description and diagnosis of Resartor on the species known at the time, but most of the species described here were not examined for that publication. With the addition of these seven new species, the description of Resartor needs to be slightly amended, as follows:

A mendment: Dorsal preantennal suture variable in extent, either not reaching $d s m s$ or ads, only reaching one of these setae, or reaching both. Parameres generally triangular (Figs. 13, 25); pst1 sensillus, located either at about mid-length of paramere (Fig. 25) or near distal end (Fig. 13); pst2 on apical tip of paramere, either sensillus (Fig. 13) or microseta (Fig. 25).

Included species:

Resartor albofulvus sp. $\mathrm{n}$.

Resartor apimimus sp. $\mathrm{n}$.

Resartor aterrimus $\mathrm{sp} . \mathrm{n}$.

Resartor effronte (Ansari, 1956: 155) [in Brueelia]

Resartor extraneus sp. $\mathrm{n}$.

Resartor grammatoptiliphagus (Mey, 2017: 170) [in Leiothrichinirmus]

Resartor guangxiensis sp. $\mathrm{n}$.

Resartor impressifrons (Ansari, 1956: 152) [in Brueelia]

Resartor longisuturalis sp. $\mathrm{n}$.

Resartor novofacies (Ansari, 1956: 154) [in Brueelia]

Resartor seminudus sp. $\mathrm{n}$.

Resartor weigoldi (Mey, 2017: 166) [in Leiothrichinirmus]

Species inquirenda

Resartor himalayanus (Mey, 2017: 169) [in Leiothrichinirmus]

Resartor himalayanus was recorded from the same host species as $R$. impressifrons, but on a different host subspecies. In the original description of $R$. himalayanus, no comparison with $R$. impressifrons is made. It is unclear whether these two species can be separated. The mesosomal lobes of both species are similar, but the angles of the lateral margins are different. Not all parts of the male genitalia of $R$. himalayanus were illustrated, and the shape of the 
Table 1. Measurements of the species of Resartor described here. Abbreviations used: TL - total length (along midline); HL - head length (along midline); HW - head width (at temples); PRW - prothoracic width; PTW - pterothoracic width; AW - abdominal width. All measurements are in millimetres.

\begin{tabular}{|c|c|c|c|c|c|c|c|c|}
\hline Louse species & Sex & $\mathrm{N}$ & $\mathrm{TL}$ & HL & HW & PRW & PTW & AW \\
\hline \multirow{2}{*}{ Leiothrix argentauris tahanensis (Yen) } & $\hat{0}$ & $4^{1}$ & $1.92-2.01$ & $0.42-0.45$ & $0.32-0.33$ & $0.22-0.24$ & $0.27-0.28$ & $0.37-0.43$ \\
\hline & 우 & 3 & $2.26-2.46$ & $0.45-0.47$ & $0.33-0.35$ & $0.24-0.26$ & $0.30-0.31$ & $0.40-0.46$ \\
\hline \multirow{2}{*}{ Heterophasia desgodinsi desgodinsi (Oustalet) } & $\sigma^{\lambda}$ & 2 & $1.82-1.98$ & $0.37-0.38$ & $0.32-0.33$ & $0.23-0.24$ & $0.27-0.29$ & $0.32-0.37$ \\
\hline & 오 & 5 & $2.17-2.30$ & $0.39-0.41$ & $0.32-0.35$ & $0.22-0.27$ & $0.27-0.31$ & $0.34-0.40$ \\
\hline Resartor apimimus sp. n. Heterophasia picaoides wrayi (Ogilvie-Grant) & $\hat{0}$ & $3^{2}$ & $1.51-1.60$ & $0.33-0.34$ & $0.27-0.28$ & $0.18-0.19$ & $0.23-0.24$ & $0.30-0.31$ \\
\hline \multirow{2}{*}{ Resartor longisuturalis sp. n.Actinodura cyanouroptera wingatei (Ogilvie-Grant) } & $\hat{0}$ & 1 & 1.92 & 0.39 & 0.30 & 0.21 & 0.25 & 0.37 \\
\hline & q & $1^{3}$ & 2.35 & 0.43 & - & 0.24 & 0.29 & 0.43 \\
\hline \multirow{2}{*}{ Resartor aterrimus sp. $\mathrm{n}$. } & $\sigma^{2}$ & 4 & $1.97-2.09$ & $0.40-0.42$ & $0.31-0.33$ & $0.22-0.25$ & $0.27-0.29$ & $0.36-0.40$ \\
\hline & 우 & $4^{4}$ & $2.31-2.44$ & $0.43-0.44$ & $0.33-0.35$ & $0.24-0.26$ & $0.28-0.31$ & $0.38-0.47$ \\
\hline \multirow{2}{*}{ Resartor extraneus sp. n. Lioparus chrysotis swinhoii (Verreaux) } & $\hat{0}$ & 3 & $1.85-1.89$ & $0.39-0.40$ & 0.31 & 0.21 & $0.25-0.27$ & $0.36-0.37$ \\
\hline & q & 3 & $2.27-2.38$ & 0.42 & $0.33-0.34$ & $0.23-0.24$ & $0.27-0.30$ & $0.41-0.44$ \\
\hline \multirow{2}{*}{ Resartor guangxiensis sp. n.Trochalopteron milnei sinianum Stresemann } & $\hat{\sigma}$ & 2 & $1.48-1.49$ & 0.38 & 0.30 & 0.21 & $0.26-0.27$ & $0.37-0.41$ \\
\hline & o & 2 & $1.98-2.00$ & $0.43-0.44$ & 0.34 & 0.24 & $0.29-0.30$ & $0.45-0.46$ \\
\hline
\end{tabular}

${ }^{1} \mathrm{~N}-3$ for $\mathrm{AW} ;{ }^{2} \mathrm{~N}-2$ for $\mathrm{AW} ;{ }^{3} \mathrm{~N}-$ left temple broken during mounting and $\mathrm{HW}$ cannot be measured; ${ }^{4} \mathrm{~N}-3 \mathrm{for}$ TL.

convergent ventral thickenings of the gonopore of $R$. impressifrons are similar to the shape of the mesosomal lobes illustrated by Mey (2017); possibly, these represent the same structure. All other figure references in Mey (2017: figs 91,93 ) refer to illustrations of $R$. grammatoptiliphagus, but it is not clear whether this is because these two species are identical in abdominal chaetotaxy or not. As the figures referred to above differ from $R$. impressifrons in the abdominal chaetotaxy, we tentatively accept $R$. himalayanus as a separate species, but note that it should be considered a species inquirenda until a redescription of this species has been published.

\section{Resartor seminudus sp. $\mathrm{n}$.}

Figs 1-7

ZooBank number for species:

urn:1sid:zoobank.org:act:ADD98E35-DB92-499D-9FD9-F2D1E95B551A

Description. Head elongated, flat-dome shaped (Fig. 3), lateral margins of preantennal area slightly convex, frons deeply concave. Dorsal preantennal suture not reaching $d s m s$ or ads. Sinuous thickening of dorsal anterior plate extends beyond posterior ends of dorsal preantennal suture. Head chaetotaxy as in Fig. 3. Coni short, wide. Temples angular. Gular plate triangular, lateral margins slightly concave. Thoracic and abdominal segments and chaetotaxy as in Figs. 1, 2. Basal apodeme slender (Fig. 4), wide section constricted. Proximal mesosome roughly trapezoidal (Fig. 5), lateral margins sinuous. Mesosomal lobes wide, angular, rugose areas present distally and proximally; 2 pmes microsetae lateral to gonopore on each side. Gonopore open only distally; proximal extensions wide, reaching to lateral margins of mesosome. Parameral heads (Fig. 6) trifid, large. Parameral blades strongly curved, not extended much distally. Female subgenital plate roughly pentagonal (Fig. 7); interrupted cross-piece with narrow connection to subgenital plate, reaching vulval margin only at extreme lateral ends. Vulval margin flattened medially, with 3-4 short, slender vms on each side, and 6-8 short, thorn-like vss on each side; 3-5 long, slender vos on each side of subgenital plate; distal 1 vos on posterior margin of cross-piece, median to vss. Measurements as in Table 1.

Type host: Leiothrix argentauris tahanensis (Yen) - silver-eared mesia (Leiothrichidae).
Type locality: Mt. Brinchang, Perak State, Malaysia $\left(101^{\circ} 38^{\prime} \mathrm{E} ; 4^{\circ} 52^{\prime} \mathrm{N}\right)$.

S pe c i men s ex a m in ed: Holotype $\hat{\sigma}$, Mt. Brinchang [Perak State], Malaysia, 20 Nov. 1961, M-00501 (OSUS). Paratypes:

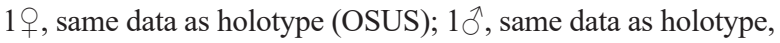
except M-00474 (OSUS); 2ภ, 2 \% , Gn. [= Gunung] Lawit, elev. 1519 m, Terengganu [Sultanate], Malaysia, 18 Mar. 1974, Gn. Lawit Expdn., Brit. Mus. 1974-2 (NHML).

E t y m o log y: The species epithet is formed by the Latin prefix "semi" for "half", and the suffix "nudus" (Latin for "naked"), referring to the scarcity of abdominal setae in the male, compared to other members of the genus.

Differential diagnosis. Resartor seminudus sp.n. is most similar to $R$. impressifrons, with which it shares the following characters: preantennal area much longer than postantennal area (Fig. 3); dorsal preantennal suture does not reach dsms (Fig. 3); sinuous thickening of dorsal anterior plate reaches far posterior to posterior end of dorsal preantennal suture (Fig. 3); psps present on male tergopleurites IV-V (Fig. 1); mesosomal lobes angular in anterior and posterior ends (Fig. 5), and with rugose areas at least distally. However, these two species can be separated by the following characters: frons narrow and deeply concave in R. seminudus (Fig. 3), but broad and shallowly concave in $R$. impressifrons; male $R$. seminudus with 1 psps on each side of abdominal segment III (Fig. 1), but no psps on male abdominal segment III in $R$. impressifrons; male $R$. impressifrons with tps on tergopleurite VI, but male $R$. seminudus without tps on tergopleurite VI (Fig. 1); female tergopleurite IX + X fused with tergopleurite XI only median to setae in $R$. impressifrons, but with more wide fusion in $R$. seminudus (Fig. 2); proximal mesosome roughly trapezoidal in $R$. seminudus (Fig. 5), but constricted at mid-length in $R$. impressifrons; gonopore open proximally in $R$. impressifrons, but closed proximally in $R$. seminudus (Fig. 5); pmes submedian in $R$. seminudus (Fig. 5), but sublateral in $R$. impressifrons; interrupted cross-piece of $R$. seminudus (Fig. 7) reaches vulval margin only at extreme lateral ends, whereas cross-piece of $R$. impressifrons reaches vulval margin for about lateral third of margin. Vulval chaetotaxy of $R$. seminudus overlapping with that of $R$. impressifrons, and females are best separated on non-genital characters. 

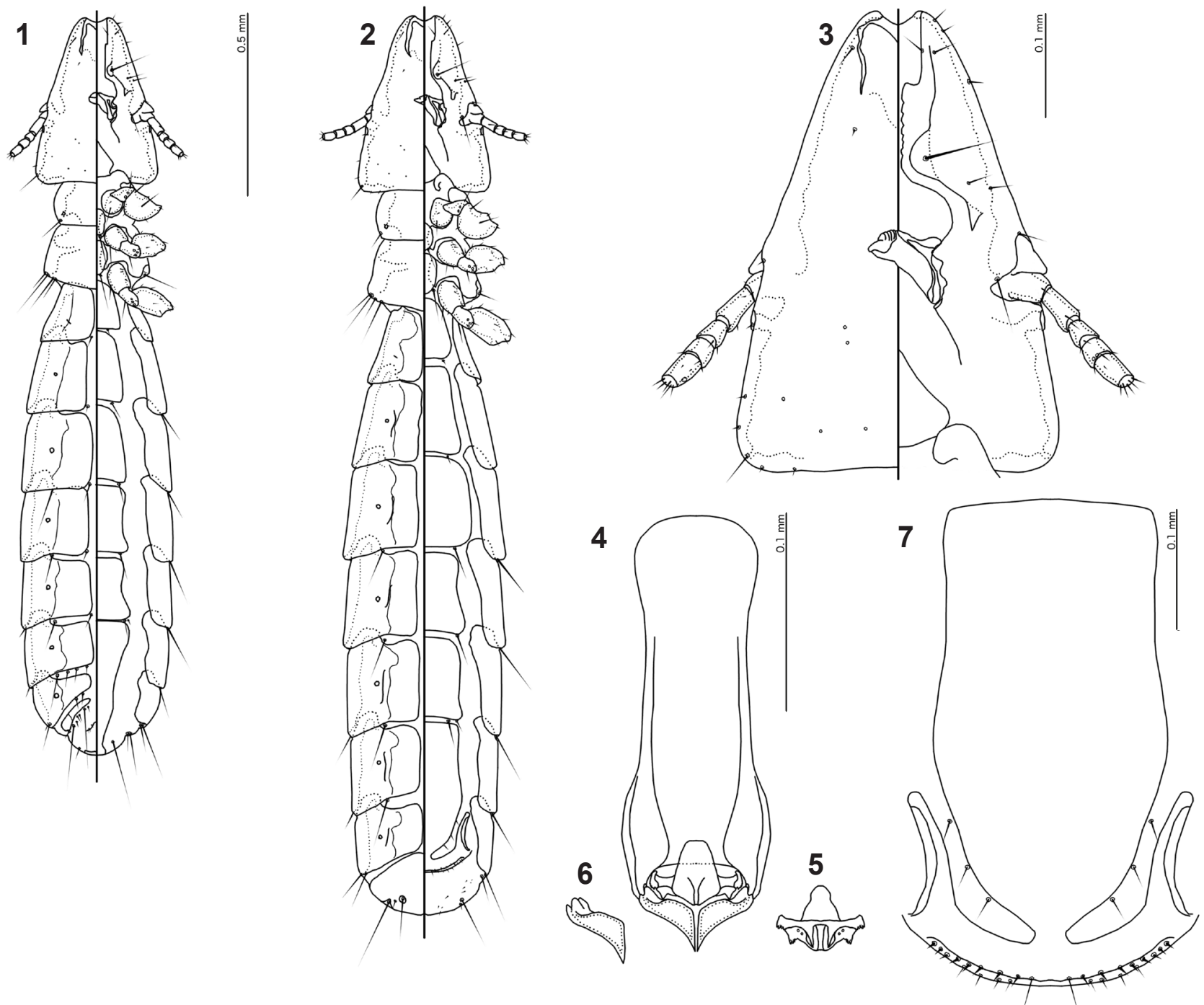

Figs. 1-7. Resartor seminudus sp. n. ex Leiothrix argentauris tahanensis (Yen). 1 - male habitus, dorsal and ventral views; $\mathbf{2}$ - female habitus, dorsal and ventral views; 3 - male head, dorsal and ventral views; $\mathbf{4}$ - male genitalia, dorsal view; 5 - male mesosome, ventral view; $\mathbf{6}$ - male paramere, dorsal view; 7 - female subgenital plate and vulval margin, ventral view.

\section{Resartor albofulvus sp. n.}

Figs. 8-14

ZooBank number for species:

urn:lsid:zoobank.org:act:9EAF81D3-DD05-4D50-B423-CDFEA87E0346

Description. Head broadly trapezoidal (Fig. 10), lateral margins of preantennal area slightly convex, frons shallowly concave. Dorsal preantennal suture reaches $d s m s$ and ads. Sinuous thickening of dorsal anterior plate not extending beyond posterior ends of dorsal preantennal suture. Head chaetotaxy as in Fig. 10. Coni short, broad. Temples almost right angle, with distinct bulge on posterior margin of head median to $m t s 3$. Gular plate rounded triangular with median point. Thoracic and abdominal segments and chaetotaxy as in Figs. 8, 9. Basal apodeme slender (Fig. 11), not constricted. Proximal mesosome slender (Fig. 12), slightly widened proximally, but without prominent antero-lateral extensions. Mesosomal lobes with several slight projections on ventral side; submedian sections of dorsal side with prominent fringed pattern. Gonopore open only distally; proximal extensions not reaching lateral margins of gonopore; lateral margin of distal gonopore with small triangular extension; 2 pmes microsetae visible on each side of gonopore. Parameral heads evidently undivided (Fig. 13); parameral blade curved, widening distally; pst $1-2$ visible as sensilla. Female subgenital plate roughly pentagonal (Fig. 14); connection to cross-piece broad. Vulval margin gently rounded, median section somewhat flattened, with 4-6 short, slender vms and 8-11 short, thornlike vss on each side of subgenital plate; 4 long, slender vos on each side of subgenital plate; distal 1 vos on posterior margin of cross-piece, median to vss. Measurements as in Table 1.

Ty p e host: Heterophasia desgodinsi desgodinsi (Oustalet)black-headed sibia.

Type loc ality: Jizushan, Dali State, Yunnan Province, China $\left(100^{\circ} 24^{\prime} \mathrm{E} ; 22^{\circ} 57^{\prime} \mathrm{N}\right)$.

S pecimens ex a mined: Holotype $\widehat{\partial}$, Jizushan, Dali State, Yunnan Province, China, 12 Sep. 2012, D. Su, J0266(4) (GIABR). Paratypes: $1 \hat{\jmath}, 1 \%$, same data as holotype, except 

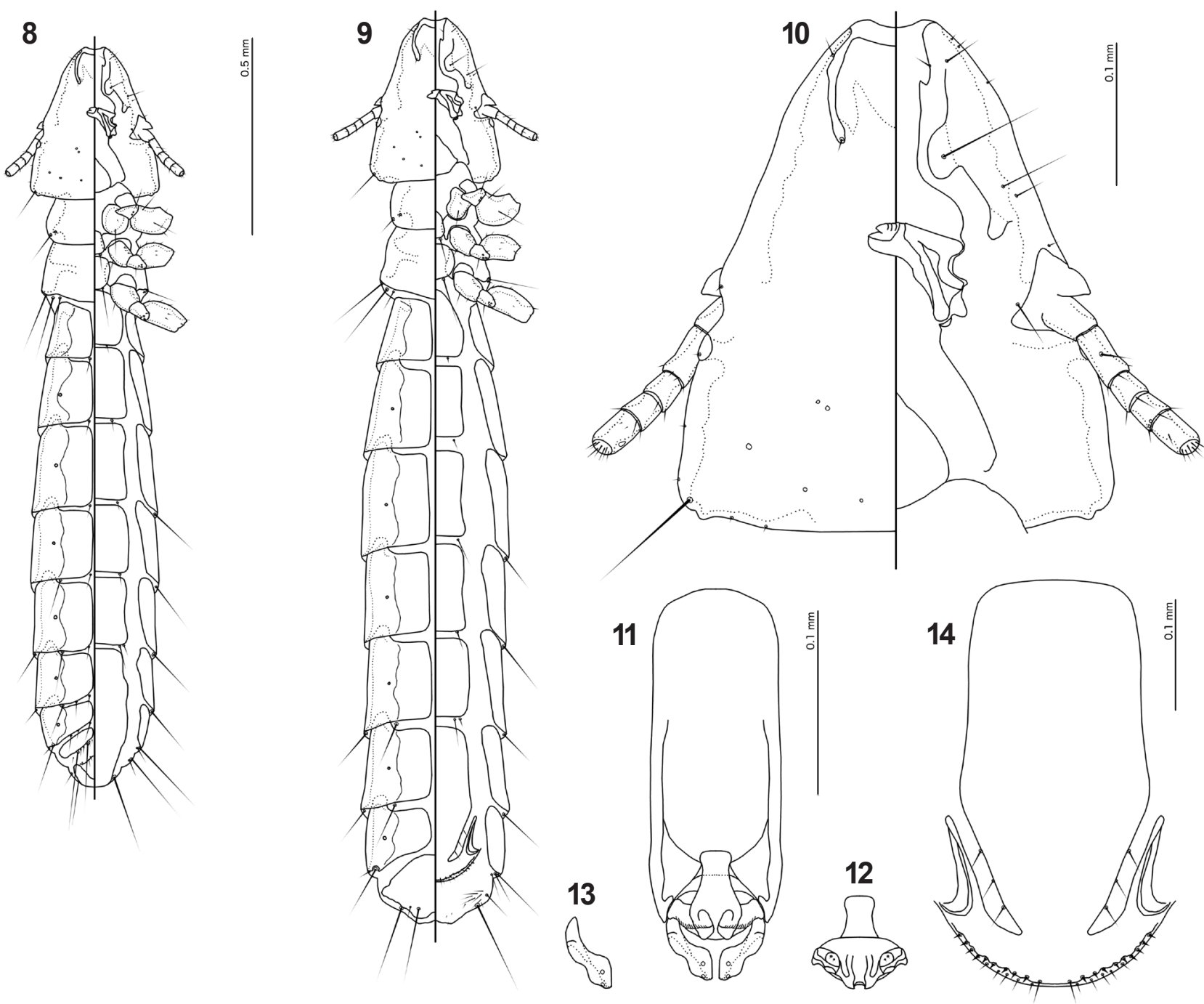

Figs. 8-14. Resartor albofulvus sp. n. ex Heterophasia desgodinsi desgodinsi (Oustalet). 8 - male habitus, dorsal and ventral views; 9 - female habitus, dorsal and ventral views; 10 - male head, dorsal and ventral views; 11 - male genitalia, dorsal view; 12 - male mesosome, ventral view; 13 - male paramere, dorsal view; $\mathbf{1 4}$ - female subgenital plate and vulval margin, ventral view.

J0266(2-3) (GIABR). 4, same locality and collector, 9 Sep. 2012, J0250 (1-2) (GIABR).

E ty mology: The species epithet is formed by "albus" (Latin for "white") and "fulvus" (Latin for "reddish-yellow"), referring to the pigmentation of this species.

Differential diagnosis. Resartor albofulvus sp. n. is most similar to $R$. apimimus sp. n., with which it shares the following characters: dorsal preantennal suture reaches dsms (Figs. 10, 16); proximal mesosome without antero-lateral extensions (Figs. 12, 18); ps absent on male abdominal segment III (Figs. 8, 15); psps absent on male tergopleurite IV (Figs.8, 15); single tps present on male tergopleurite (Figs. 8, 15). However, these two species can be separated by the following characters: postero-lateral margins of mesosomal lobes with several small triangular extensions in $R$. albofulvus (Fig. 12), but smooth in $R$. apimimus (Fig 18); distal gonopore with small triangular extension on lateral margin in $R$. albofulvus (Fig. 12), but smooth in $R$. apimimus (Fig. 18); male tergopleurite $\mathrm{V}$ with psps in $R$ albofulvus (Fig. 8), but without psps in $R$. api- mimus (Fig. 15); male tergopleurite VI without tps in $R$. albofulvus (Fig. 8), but with tps in R. apimimus (Fig. 15); dorsal preantennal suture reaches ads in $R$. albofulvus (Fig. 10 ), but not in R. apimimus (Fig. 16). Females of R. apimimus unknown, and no comparison can be made.

Remarks. The proximal mesosome of both males examined is partially obscured by gut content, and is here illustrated as close to the actual shape as possible. The type host is sometimes considered a subspecies of Heterophasia melanoleuca (Blyth).

\section{Resartor apimimus sp. $\mathrm{n}$.}

Figs. 15-19

\section{ZooBank number for species:}

urn:lsid:zoobank.org:act:ABDED906-C0DF-48E6-A089-4B00FB8AAFDD

Description. Head trapezoidal (Fig. 16), with slightly convex lateral margins of preantennal area and more or less flat frons. Dorsal preantennal suture reaches $d s m s$ but not $a d s$. Sinuous posterior thickening of dorsal anterior plate extending beyond posterior ends of dorsal preantennal 


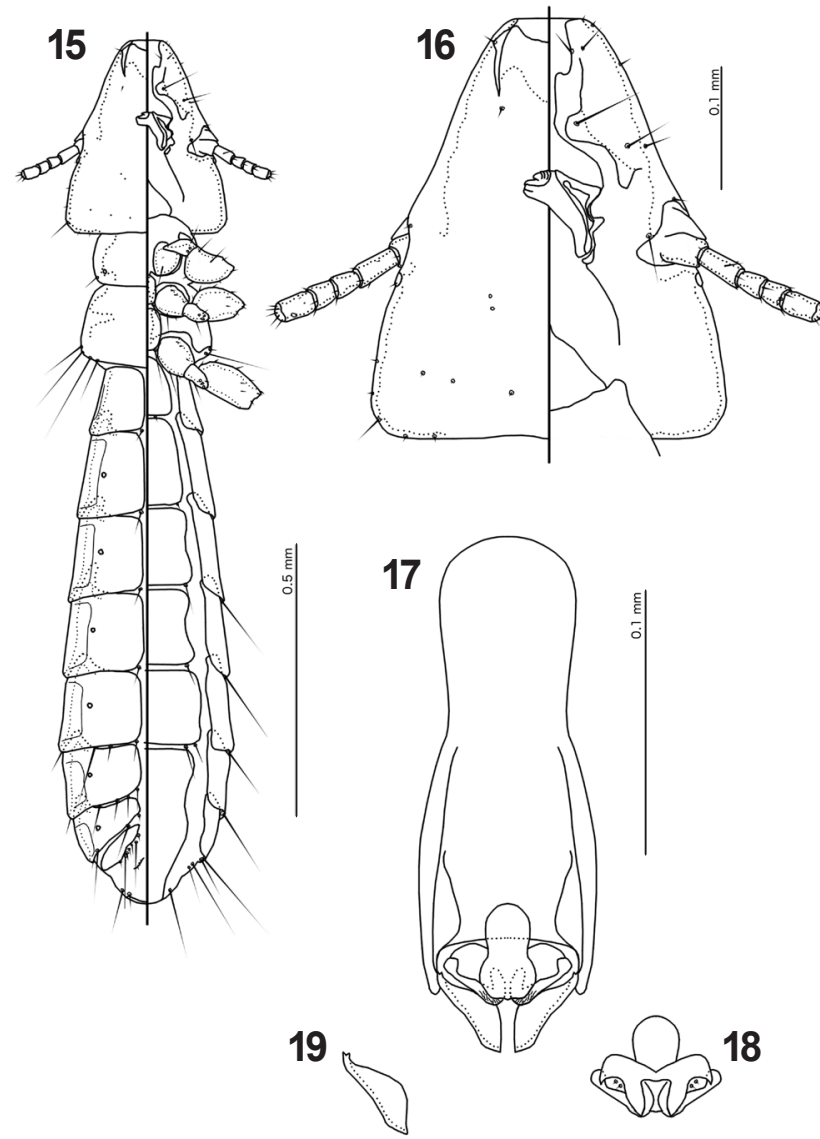

Figs. 15-19. Resartor apimimus sp. n. ex Heterophasia picaoides wrayi (Ogilvie-Grant). 15 - male habitus, dorsal and ventral views. 16 - male head, dorsal and ventral views. 17 - male genitalia, dorsal view. 18 - male mesosome, ventral view. 19 - male paramere, dorsal view.

suture. Head chaetotaxy as in Fig. 16. Coni short, slender. Temples rounded, slightly acute. Gular plate roughly triangular, lateral margins convex. Thoracic and abdominal segments and chaetotaxy as in Fig. 15. Basal apodeme (Fig. 17) slender, lateral margins constricted in proximal half. Proximal mesosome rounded (Fig 18). Mesosomal lobes wide, rounded, without rugose areas; 2 pmes microsetae on each side lateral to gonopore. Gonopore open only distally; antero-lateral extensions do not reach lateral margins of mesosomal lobes, curved posteriorly. Parameral heads minute (Fig. 19), bifid. Parameral blades not elongated, roughly triangular; pst 1-2 not visible. Measurements as in Table 1.

Type host: Heterophasia picaoides wrayi (Ogilvie-Grant)long-tailed sibia (Leiothrichidae).

Type locality: Mt. Brinchang, Perak State, Malaysia $\left(101^{\circ} 38^{\prime} \mathrm{E} ; 4^{\circ} 52^{\prime} \mathrm{N}\right)$.

S pecimens ex a mined: Holotype $\widehat{\jmath}$, Mt. Brinchang [Perak State], Malaysia, 22 Nov. 1961, M-00483 (OSUS). Paratypes: $2 \hat{\jmath}$, same data as holotype (OSUS).

E ty m o log y: The species epithet is formed from "apis" (Latin for "bee") and "mimus" (Latin for "imitator, mime"), referring to the abdominal pigmentation pattern of $R$. apimimus, which is unique within the genus. The dark sections of the tergopleurites alternate with pale orange-brown pleural incrassations, giving the abdomen bee-stripe appearance.
Differential diagnosis. Resartor apimimus is most similar to $R$. albofulvus, with which it shares the following characters: dorsal preantennal suture reaches dsms (Figs. 10, 16); proximal mesosome without antero-lateral extensions (Figs. 12, 18); ps absent on male abdominal segment III (Figs. 8, 15); psps absent on male tergopleurite IV (Figs. 8, 15); single tps present on male tergopleurite (Figs. 8, 15). However, these two species can be separated by the following characters: mesosomal lobes with flat postero-lateral margins in $R$. apimimus (Fig. 18), but with several small triangular projections in R. albofulvus (Fig. 12); gonopore shape different (Figs. 12, 18); male tergopleurite V without psps in R. apimimus (Fig. 15), but with psps in $R$. albofulvus (Fig. 8); male tergopleurite VI with 1 tps in $R$. apimimus (Fig. 15), but without tps in R. albofulvus (Fig. 8); dorsal preantennal suture does not reach ads in $R$. apimimus (Fig. 16), but reaches ads in $R$. albofulvus (Fig. 10). Females of $R$. apimimus unknown and thus no comparison can be made.

Remarks. The female of $R$. apimimus is presently unknown and we base this description on male characters only. These are sufficient to separate this species from all other known Resartor species. We therefore describe this species despite having seen no females, to facilitate future discussion on the morphological variation and host range in babbler lice.

\section{Resartor longisuturalis sp. n.}

Figs. 20-26

ZooBank number for species:

urn:Isid:zoobank.org:act:0E5BAD66-DB7F-423B-B782-8510A088DFA9

Description. Head trapezoidal (Fig. 22), lateral margins of preantennal area slightly convex, frons shallowly concave. Dorsal preantennal suture reaching $a d s$ and $d s m s$. Sinuous thickening of dorsal preantennal plate does not extend beyond posterior end of dorsal preantennal suture. Head chaetotaxy as in Fig. 22. Coni short, slender. Temples rounded, slightly acute. Gular plate with concave antero-lateral margins. Thoracic and abdominal segments and chaetotaxy as in Figs. 20, 21. Basal apodeme broad (Fig. 23), not constricted, widening distally. Proximal mesosome with flat anterior margin and prominent antero-lateral extensions (Fig. 24a). Mesosomal lobes angular, converging distally, with two rugose areas on each side (Fig. 24b), and 2 pmes setae visible as microsetae on lateral margin on each side. Gonopore open only distally, with prominent antero-lateral extensions that almost reach lateral margins of mesosome; 2 pmes microsetae lateral to gonopore on each side. Parameres blunt (Fig. 25); parameral blades somewhat elongated, with slight lateral bulge in distal half; pst 1 as sensillus at about mid-length; pst 2 as distal microseta. Female subgenital plate with sinuous lateral margins (Fig. 26), narrowly connected to cross-piece. Vulval margin gently rounded or slightly flattened medially, with 4 short, slender $v m s$ and 7 short, thorn-like vss on each side; 3 long, slender vos on each side of subgenital plate; distal 1 vos on posterior margin of subgenital plate, just anterior to vss. Measurements as in Table 1. 

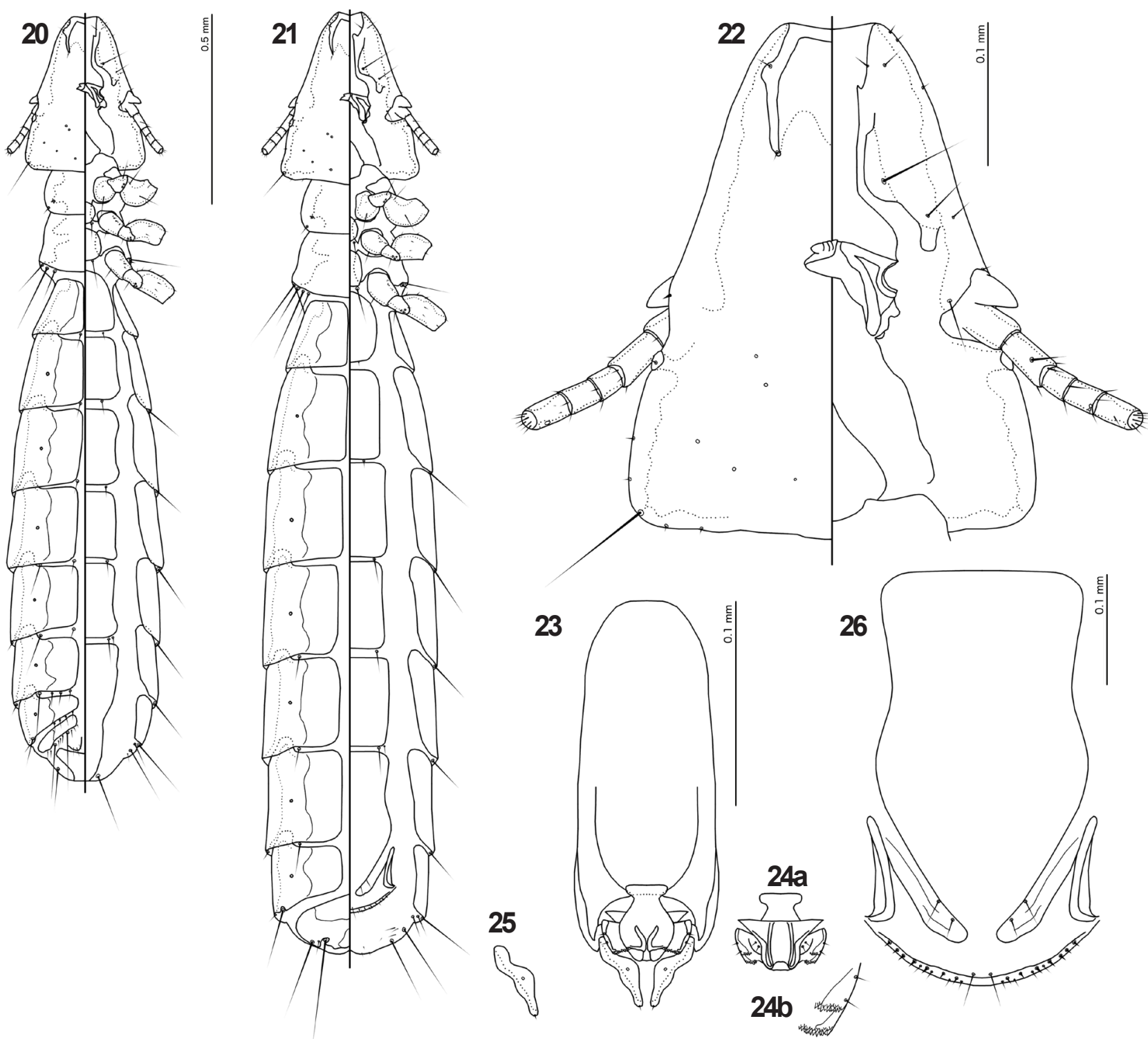

Figs. 20-26. Resartor longisuturalis sp. n. ex Actinodura cyanouroptera wingatei (Ogilvie-Grant); 20 - male habitus, dorsal and ventral views; $\mathbf{2 1}$ - female habitus, dorsal and ventral views; $\mathbf{2 2}$ - male head, dorsal and ventral views; $\mathbf{2 3}$ - male genitalia, dorsal view; $\mathbf{2 4 a}$ - male mesosome, ventral view; $\mathbf{2 4 b}$ - lateral margin of mesosomal lobes, ventral view, not to scale; $\mathbf{2 5}$ - male paramere, dorsal view; 26 - female subgenital plate and vulval margin, ventral view.

Type host: Actinodura cyanouroptera wingatei (Ogilvie-Grant) - blue-winged minla.

Type locality: Daweishan, Honghe State, Yunnan Province, China $\left(103^{\circ} 41^{\prime} \mathrm{E} ; 22^{\circ} 57^{\prime} \mathrm{N}\right)$.

Specimens examined: Holotype $\hat{\sigma}$, Daweishan, Honghe State, Yunnan Province, China, 21 Aug. 2012, D. Su, J0178(1) (GIABR). Paratypes: 10, 1q, same data as holotype (GIABR).

E ty mology: The species epithet is formed by "longus" (Latin for "long") and "sutura" (Latin for "seam"), referring to the dorsal preantennal suture reaching the ads.

Differential diagnosis. Resartor longisuturalis sp. n. is most similar to $R$. aterrimus, with which it shares the following characters: dorsal preantennal suture reaches both dsms and ads (Figs. 22, 29); psps present on male tergopleurite V (Figs. 20, 27); ps present on male abdom- inal segment III (Figs. 22, 27); proximal mesosome with antero-lateral extensions (Figs. 24a, 31a); median section of gonopore long, near rectangular (Figs. 24a, 31a). However, these two species can be separated by the following characters: psps present on female tergopleurite IV in $R$. aterrimus (Fig. 28), but absent in R. longisuturalis (Fig. 21 ); female subgenital plate with deep lateral constriction in anterior third in R. longisuturalis (Fig. 26), but no or only shallow construction in $R$. atrerrimus (Fig. 33); connection between subgenital plate and cross-piece narrow in $R$. longisuturalis (Fig. 26), but broad in R. aterrimus (Fig. 33 ); mesosomal lobes with two small rugose areas per side in $R$. longisuturalis (Fig. 24b), but with only rugose distal margin in $R$. aterrimus (Fig. 31b); pmes on lateral margins of mesosomal lobes visible as microsetae in $R$. longisuturalis (Fig. 24a), but not visible in $R$. aterrimus (Fig. 31a). 

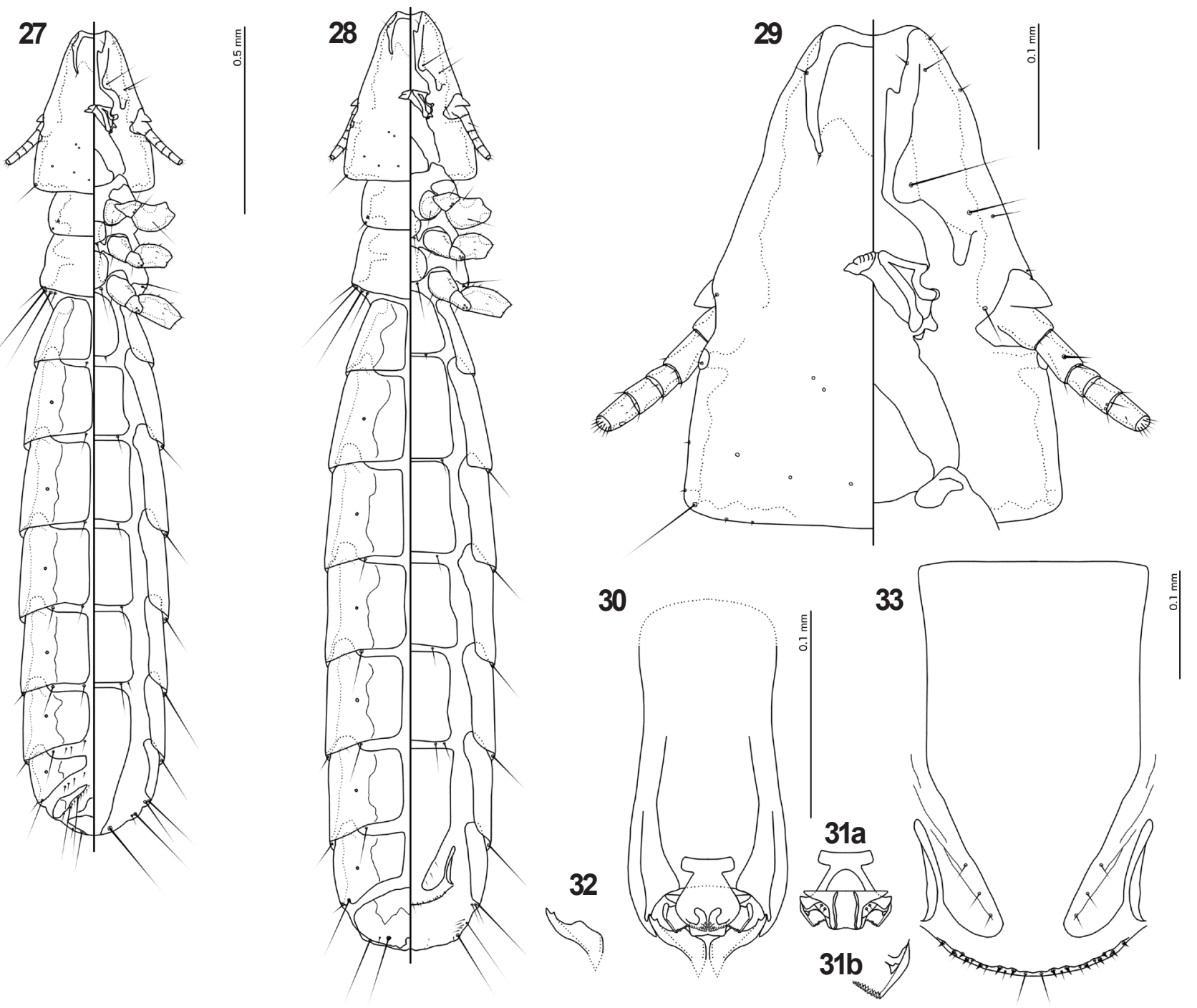

Figs. 27-33. Resartor aterrimus sp. n. ex Minla ignotincta mariae La Touche. $\mathbf{2 7}$ - male habitus, dorsal and ventral views; 28 - female habitus, dorsal and ventral views; 29 - male head, dorsal and ventral views; 30 - male genitalia, dorsal view; 31a - male mesosome, ventral view; $\mathbf{3 1 b}$ - lateral margin of mesosomal lobes, ventral view, not to scale; 32 - male paramere, dorsal view; 33 - female subgenital plate and vulval margin, ventral view.

\section{Resartor aterrimus sp. $\mathrm{n}$.}

Figs. 27-33

ZooBank number for species:

urn:lsid:zoobank.org:act:EC365282-F071-480B-BAB9-DCA109810E24

Description. Head trapezoidal (Fig. 29), lateral margins of preantennal area clearly convex in anterior section, frons broad, shallowly concave. Dorsal preantennal suture reaches $d s m s$ and $a d s$. Sinuous thickening of dorsal preantennal plate extends as far posterior as dorsal preantennal suture. Head chaetotaxy as in Fig. 29. Cone short, stout. Temples almost right angles. Gular plate with convex antero-lateral margins. Thoracic and abdominal segments and chaetotaxy as in Figs. 27, 28. Basal apodeme broad (Fig. 30), lateral margins constricted at mid-length. Proximal mesosome with prominent antero-lateral extensions (Fig. 31a) and slightly concave anterior margin. Mesosomal lobes long, with rugose distal margin (Fig. 31b). Gonopore open only distally, with short, slender antero-lateral extensions not reaching lateral margins of mesosome; 2 pmes microsetae on each side of gonopore. Parameral heads unequally bifid (Fig. 32); parameral blades broad, extended distally, but partially everted in all examined specimens and exact shape unknown. Female subgenital plate slender and pentagonal (Fig. 33), lateral margins of anterior part slightly convergent distally; connection to cross-piece broad. Vulval margin gently rounded or somewhat flattened medially, with 3-5 short, slender vms and 5-7 short, thorn-like vss on each side; 3-4 long, slender vos on each side of subgenital plate; distal 1 vos on posterior margin of subgenital plate, median to vss. Measurements as in Table 1.

Type host: Minla ignotincta mariae La Touche - red-tailed minla (Leiothrichidae).

Type locality: Daweishan, Honghe State, Yunnan Province, China $\left(103^{\circ} 41^{\prime} \mathrm{E} ; 22^{\circ} 57^{\prime} \mathrm{N}\right)$.

Specimens examined: Holotype $\partial$, Daweishan, Honghe State, Yunnan Province, China, 21 Aug. 2012, D. $\mathrm{Su}, \mathrm{J} 0176(5)$ [lower male, arranged vertically on slide; 
34

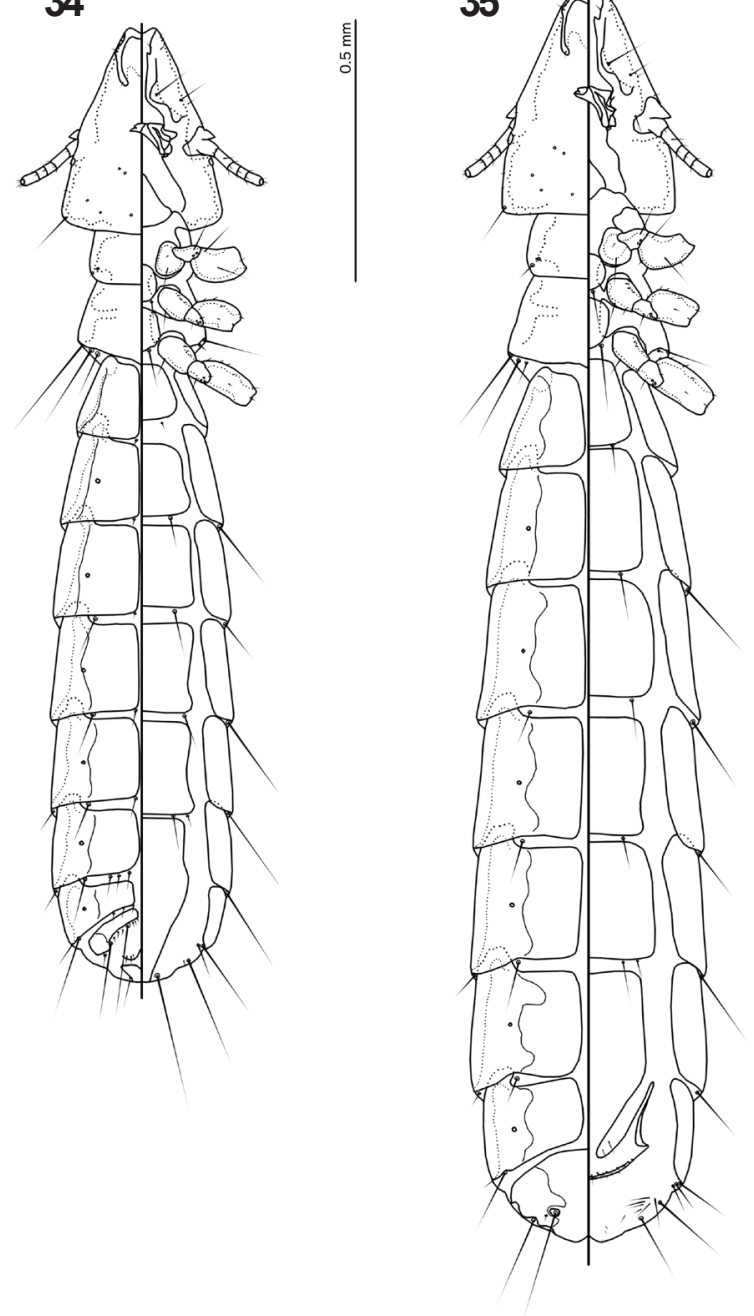

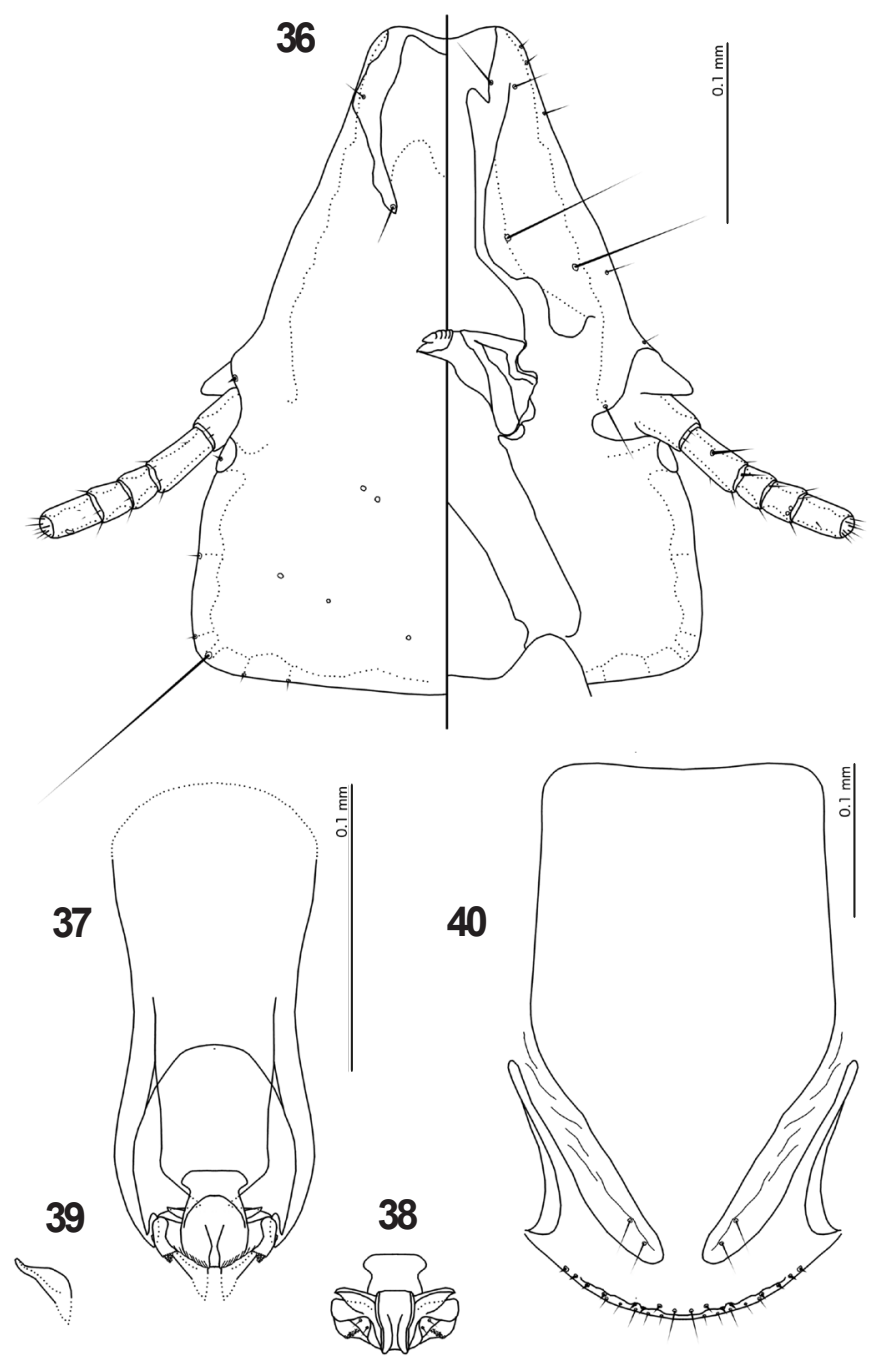

Figs. 34-40. Resartor extraneus sp. n. ex Lioparus chrysotis swinhoii (Verreuax). 34 - male habitus, dorsal and ventral views; 35 - female habitus, dorsal and ventral views; 36 - male head, dorsal and ventral views; 37 - male genitalia, dorsal view; 38 - male mesosome, ventral view; 39 - male paramere, dorsal view; 40 - female subgenital plate and vulval margin, ventral view.

marked on slide] (GIABR). Paratypes: $3 \hat{\jmath}, 4 \uparrow$, same data as holotype J0176(1-3) (GIABR).

Etymology: The species epithet derives from "aterrimus" (Latin for "blackest"), referring to the very dark margins on the abdomen.

Differential diagnosis. Resartor aterrimus sp. n. is most similar to $R$. longisuturalis, with which it shares the following characters: dorsal preantennal suture reaches both dsms and ads (Figs. 22, 29); psps present on male tergopleurite V (Figs. 20, 27); ps present on male abdominal segment III (Figs. 22, 27); proximal mesosome with antero-lateral extensions (Figs. 24a, 31a); median section of gonopore long, near rectangular (Figs. 24a, 31a). However, these two species can be separated by the following characters: psps present on female tergopleurite IV in $R$. aterrimus (Fig. 28), but absent in R. longisuturalis (Fig. $21)$; female subgenital plate roughly pentagonal with shallowly concave lateral margins and broad connection to cross-piece in $R$. aterrimus (Fig. 33), but with highly sinuous lateral margins and narrow connection to cross-piece in $R$. longisuturalis (Fig. 26); mesosomal lobes with two rugose areas per side in $R$. longisuturalis (Fig. 24b), but with only rugose distal margin in $R$. aterrimus (Fig. $31 \mathrm{~b}$ ); pmes on lateral margins of mesosomal lobes visible as microsetae in $R$. longisuturalis (Fig. 24a), but not visible in $R$. aterrimus (Fig. 31a).

Remarks. The anterior end of the basal apodeme is obscured by gut content in all examined males, and it is here illustrated as accurately as possible based on what can be seen in specimens.

\section{Resartor extraneus sp. n.}

Figs. 34-40

ZooBank number for species:

urn:Isid:zoobank.org:act:AF97B288-A484-4A84-8D79-143765E747F3

Description. Head trapezoidal (Fig. 36), frons broadly concave. Dorsal preantennal suture reaches $d s m s$ and ads, almost reaches lateral margins of head near dsms. Sinuous thickening of dorsal preantennal plate not extend beyond 

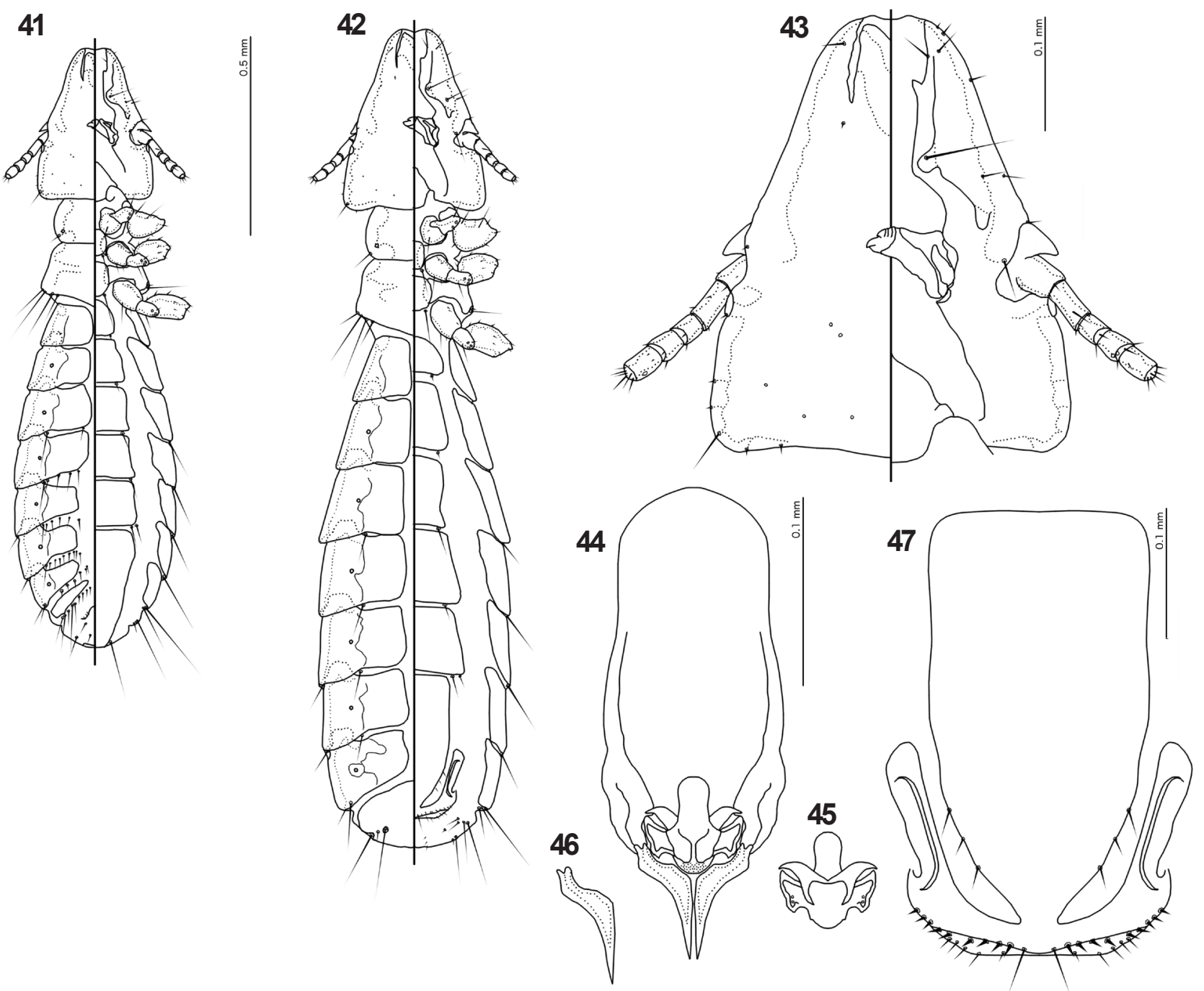

Figs. 41-47. Resartor guangxiensis sp. n. ex Trochalopteron milnei sinianum Stresemann. $\mathbf{4 1}$ - male habitus, dorsal and ventral views; $\mathbf{4 2}$ - female habitus, dorsal and ventral views. $\mathbf{4 3}$ - male head, dorsal and ventral views; $\mathbf{4 4}$ - male genitalia, dorsal view; $\mathbf{4 5}$ - male mesosome, ventral view; $\mathbf{4 6}$ - male paramere, dorsal view; $\mathbf{4 7}$ - female subgenital plate and vulval margin, ventral view.

posterior point of dorsal preantennal suture. Head chaetotaxy as in Fig. 36. Coni short, slender. Temples almost right angles. Thoracic and abdominal segments and chaetotaxy as in Figs. 34, 35. Basal apodeme slender (Fig. 37), constricted at mid-point. Proximal mesosome with antero-lateral bulges (Fig. 38). Mesosomal lobes broad, roughly rounded posteriorly, with 1 extensive rugose patch on each side; 2 pmes microsetae visible on each side of gonopore. Gonopore open only distally; proximal extensions wide, almost reaching lateral margins of mesosome, slightly recurved distally. Parameral heads narrow (Fig. 39); parameral blades partially everted in all examined males and distal sections here illustrated tentatively. Female subgenital plate roughly pentagonal (Fig. 40), with straight or slightly concave lateral margins; connection to cross-piece narrow. Vulval margin gently rounded, with 4-5 short, slender vms and 6-7 short, slender vss on each side; 2-4 long, slender vos on each side of subgenital plate; distal 1 vos near posterior margin of subgenital plate, median to vss. Measurements as in Table 1.
Type host: Lioparus chrysotis swinhoii (Verreuax) - golden-breasted fulvetta (Paradoxornithidae).

Type locality: Laojunshan, Sichuan Province, China $\left(104^{\circ} 11^{\prime} \mathrm{E} 28^{\circ} 42^{\prime} \mathrm{N}\right)$.

Specimens examined: Holotype $\hat{\partial}$, Laojunshan, Sichuan Province, China, 11 Aug. 2014, Y. Zhao, Y. Zhang, X. Chu, W. Li, J2271 [male closest to locality label, to the right on the slide] (GIABR). Paratypes: 1ð̂, $2 q$, same data as holotype (GIABR). 1을 same data as holotype, except 12 Aug. 2014, J2272 (1) (GIABR). 1 $\partial^{\lambda}$, same data as holotype, except 10 Aug. 2014, J2266(1) (GIABR).

E t y m o log y: The species epithet derives from "extraneus" (Latin for "foreign"), referring to the fact that this is the only species of Resartor known from a host outside the Leiothrichidae.

Differential diagnosis. Resartor extraneus sp. $\mathrm{n}$. is not morphologically similar to any other known species in the genus. The following combination of characters separates it from all other Resartor species: psps present on tergopleurite IV in both sexes (Figs. 34, 35); ps present on male abdominal segment III (Fig. 34); dorsal preantennal suture reaches both $a d s$ and $d s m s$, and almost reaches lateral head margin near $d s m s$ (Fig. 36). 
Remarks. The anterior end of the basal apodeme is obscured by gut content in all examined males, and it is here illustrated tentatively. Slides J2266 and J2271 also include one nymph each, which are not described here.

\section{Resartor guangxiensis sp. n.}

Figs. 41-47

\section{ZooBank number for species:}

urn:lsid:zoobank.org:act:CA53333D-C481-45C5-8387-04D6B5C06669

Description. Head rounded trapezoidal (Fig. 43), frons slightly concave. Dorsal preantennal suture not reaching $d s m s$ or ads. Sinuous posterior thickening of dorsal anterior plate extending posterior to ads. Head chaetotaxy as in Fig. 43. Coni short, broad. Temples rounded, slightly acute. Gular plate roughly triangular, antero-lateral margins convex. Thoracic and abdominal segments and chaetotaxy as in Figs. 41, 42. Basal apodeme broad (Fig. 44), lateral margins convex. Proximal mesosome slender, rounded (Fig. 45). Mesosomal lobes angular anteriorly and posteriorly; 2 pmes sensilla on each side near lateral margins of mesosomal lobes; distal end of mesosome rounded. Gonopore open only distally, but antero-median section narrow; antero-lateral extensions broad, curved, pointed. Parameral heads bifid (Fig. 46). Parameral blades elongated distally, slender; $p s t 1-2$ not visible. Female subgenital plate roughly pentagonal (Fig. 47), lateral margins more or less straight, narrowly connected to cross-piece. Vulval margin broadly flattened medianly, with 5-6 short, slender $v m s$ on each side and 8-10 short, thorn-like vss on each side; 3-4 long, slender vos on each side; distal 1 vos on posterior margin of cross-piece, and median to vss. Measurements as in Table 1.

Type host: Trochalopteron milnei sinianum Stresemann, - red-tailed laughing-thrush (Leiothrichidae).

Type locality: Jingxi County, Guangxi Province, China $\left(106^{\circ} 25^{\prime} \mathrm{E} ; 23^{\circ} 08^{\prime} \mathrm{N}\right)$.

Specimens examined: Holotype $\widehat{O}$, Jingxin County, Guangxi Province, China, 28 Sep. 2004, S.E. Bush, host ATP2004-108, P\#314, PIPeR \# 81 (NHML) [marked with black dot on slide]. Paratypes: $1 \delta^{\lambda}, 1+$, same data as holotype (PIPeR); 1 , same data as holotype, except host AN-426, P\#316, PIPeR \#82 (PIPeR).

E ty m o log y: The species epithet derives from the name of the Chinese province that includes the type locality.

Differential diagnosis. Resartor guangxiensis sp. $\mathrm{n}$. has rows of tps on male tergopleurites V-VI, and thus is most similar to $R$. effronte, $R$. novofacies, and $R$. weigoldi. It is separated from these species by the following characters: at least 1 tps on male tergopleurite IV in $R$. effronte and $R$. novofacies (the state of this character is unknown for $R$. weigoldi), but no tps on male tergopleurite IV in $R$. guangxiensis (Fig. 41); proximal mesosome flaring proximally in $R$. effronte, $R$. weigoldi, and $R$. novofacies, but not flaring in $R$. guangxiensis (Fig. 45); distal mesosome flattened in $R$. effronte and $R$. novofacies, but rounded in $R$. guangxiensis (Fig. 45) (this character is obscured in the illustration of $R$. weigoldi, and the state in this species is thus unknown). Vulval chaetotaxy overlaps between $R$. novofacies, $R$. effronte and $R$. guangxiensis, and is unknown in $R$. weigoldi.

\section{DISCUSSION}

The new species described here expand both the known diversity of Resartor and the known host range for the genus. With two exceptions, all the hosts of Resartor belong to the same clade within Leiothrichidae (Cibois 2003, fig. 4 , clade 8 , plus the clade immediately below, Luo et al. 2008, fig. 2, clades B + C, Moyle et al. 2012, Fig. 3A, lower half). This clade contains hosts of the genera Actinodura Gould, Crocias Temminck, Heterophasia Blyth, Leiothrix Swainson, Liocichla Swinhoe, Minla Hodgson, Montecincla Robin and Trochalopteron Blyth (Luo et al. 2008, Moyle et al. 2012, Robin et al. 2017). No species of Resartor are known from the host genera Crocias, Liocichla and Montecincla. Moreover, lice of the genus Resartor are known from only 11 of 50 species in this host group. The potential species diversity of this genus may thus be substantial.

Two species of Resartor, which have been described from hosts outside this clade, are of particular interest. First, Resartor grammatoptiliphagus was described from Grammatoptila striata (Vigors), a bird species that has been placed as the sister of all or almost all other members of Leiothrichidae (Moyle et al. 2012, Robin et al. 2017). The community of louse species belonging to the Brueelia-complex parasitic on $G$. striata is peculiar: this is the only host species known to be parasitised by species of both Resartor and Priceiella (Gustafsson and Bush 2017, Gustafsson et al. 2018), and it is the only host of the louse species placed in the monotypic genus Ceratocista.

The second species, Resartor extraneus sp. n., is known from Lioparus chrysotis, a bird species placed outside that clade, and is the first species of Resartor known from a host outside the Leiothrichidae, i.e. from the Paradoxornithidae. However, the two host families are not particularly closely related within the Sylvioidea (Cibois 2003, Pasquet et al. 2006, Gelang et al. 2008, Moyle et al. 2012). We have not found specimens of Resartor on members of other host families that are closely related to Leiothrichidae or Paradoxornithidae, such as Pellorneidae, Timaliidae and Zosteropidae (Gelang et al. 2008).

It is possible that the host associations of both $R$. grammatoptiliphagus and $R$. extraneus are the result of host switches. Alternatively, the presence of Resartor species on G. striata and L. chrysotis may indicate that this louse genus has a wider host distribution than currently known. Most species in the babbler families (i.e. Leiothrichidae, Paradoxornithidae, Pellorneidae, Timaliidae) have never been sampled for lice. More rigorous sampling of these hosts is needed to address this issue. 


\section{Checklist of the species included in the genus Resartor}

This checklist is arranged alphabetically by louse species name, with known hosts indented below, with host order and family names in square brackets, according to the taxonomy of Clements (2017).

Resartor albofulvus sp. $\mathrm{n}$.

Heterophasia desgodinsi desgodinsi (Oustalet) [Passeriformes: Leiothrichidae]

Resartor apimimus sp. n.

Heterophasia picaoides wrayi (Ogilvie-Grant) [Passeriformes: Leiothrichidae]

Resartor aterrimus sp. $\mathrm{n}$. Minla ignotincta Hodgson [Passeriformes: Leiothrichidae]

Resartor effronte (Ansari, 1956)

Trochalopteron squamatum (Gould) [Passeriformes: Leiothrichidae]

Resartor extraneus sp. $\mathrm{n}$.

Lioparus chrysotis (Blyth) [Passeriformes: Paradoxornithidae]

Resartor grammatoptiliphagus (Mey, 2017)

Grammatoptila striata sikkimensis Ticehurst [Passeriformes: Leiothrichidae]

Resartor guangxiensis sp. $\mathrm{n}$.

Trochalopteron milnei sinianum Stresemann [Passeriformes: Leiothrichidae]

Resartor himalayanus (Mey, 2017) Species inquirenda Trochalopteron affine blythii Verreaux [Passeriformes: Leiothrichidae]

Resartor impressifrons (Ansari, 1956)

Trochalopteron affine affine (Blyth) [Passeriformes: Leiothrich.]

Trochalopteron affine bethelae (Rand et Flemming) [Passeriformes: Leiothrichidae]

Resartor longisuturalis sp. $\mathrm{n}$.

Actinodura cyanouroptera wingatei (Ogilvie-Grant) [Passeriformes: Leiothrichidae]

Resartor novofacies (Ansari, 1956)

Trochalopteron subunicolor subunicolor Blyth [Passeriformes: Leiothrichidae]

Resartor seminudus sp. $\mathrm{n}$.

Leiothrix argentauris tahanensis (Yen) [Passeriformes: Leiothrichidae]

Resartor weigoldi (Mey, 2017)

Trochalopteron formosum formosum Verreaux [Passeriformes: Leiothrichidae]

\section{Host-louse checklist of species included in the genus Resartor}

This checklist is arranged alphabetically by host family, genus and species according to the taxonomy of Clements et al. (2017), with louse taxa indented below each host.

Leiothrichidae (laughing-thrushes and allies) Actinodura cyanouroptera wingatei (Ogilvie-Grant)

Resartor longisuturalis $\mathrm{sp} . \mathrm{n}$. Grammatoptila striata sikkimensis Ticehurst

Resartor grammatoptiliphagus (Mey, 2017)

Heterophasia desgodinsi desgodinsi (Oustalet)
Resartor albofulvus sp. $\mathrm{n}$.

Heterophasia picaoides wrayi (Ogilvie-Grant)

Resartor apimimus sp. $\mathrm{n}$.

Leiothrix argentauris tahanensis (Yen)

Resartor seminudus sp. $\mathrm{n}$. Minla ignotincta Hodgson

Resartor aterrimus sp. $\mathrm{n}$. Trochalopteron affine affine (Blyth)

Resartor impressifrons (Ansari, 1956)

Trochalopteron affine bethelae (Rand et Flemming)

Resartor impressifrons (Ansari, 1956)

Trochalopteron affine blythii Verreaux

Resartor himalayanus (Mey, 2017) - species inquirenda

Trochalopteron formosum formosum Verreaux

Resartor weigoldi (Mey, 2017)

Trochalopteron milnei sinianum Stresemann

Resartor guangxiensis $\mathrm{sp} . \mathrm{n}$.

Trochalopteron squamatum (Gould)

Resartor effronte (Ansari, 1956)

Trochalopteron subunicolor subunicolor Blyth

Resartor novofacies (Ansari, 1956)

Paradoxornithidae (parrotbills, wrentits and allies)

Lioparus chrysotis (Blyth)

Resartor extraneus sp. $\mathrm{n}$.

\section{Key to the species of the genus Resartor}

The accuracy of the key below is limited by a few factors. First, $R$. weigoldi, $R$. himalayanus and $R$. grammatoptiliphagus were not sufficiently described or illustrated by Mey (2017) to assess several key characters, and the type specimens are currently unavailable (Karla Schneider, pers. comm.). Therefore, those three species are only tentatively included in this key. Once material of these species becomes available for study, their placement may change.

In addition, females of $R$. apimimus and $R$. grammatoptiliphagus are unknown, and no morphological characters other than measurements are available for females of $R$. weigoldi and $R$. himalayanus. Females of these four species are therefore excluded from the key.

1. Males 2

-. Females ................................................................... 14

2. Setal rows present on tergopleurites V-VI.............. 3

-. Setal rows absent on tergopleurites V-VI............... 6

3. Proximal mesosome flaring in anterior end; at least 1 tps present on tergopleurite IV (chaetotaxy of abdominal segment IV unknown for $R$. weigoldi)

-. Proximal mesosome not flaring in anterior end (Fig. 45); no tps on tergopleurite IV (Fig. 41).... R. guangxiensis

4. Male abdominal segment III with 1 ps on each side .. R. effronte

-. Male abdominal segment III with no ps (none visible in photo of $R$. weigoldi, but may be too short to be seen).. 5 
5. Proximal mesosome T-shaped R. novofacies

-. Proximal mesosome Y-shaped R. weigoldi

6. Tergal posterior setae absent on tergopleurite VIII [Note: this character may be an error in Mey's (2017) illustrations].

-. Tergal posterior setae present on tergopleurite VIII... 8

7. Parameres long and slender.... R. grammatoptiliphagus

-. Parameres apparently short and broad (but distorted in original description) $R$. himalayanus

8. Dorsal preantennal suture does not reach $d s m s$ (Fig. 3) .. 9

-. Dorsal preantennal suture reaches $d s m s$ (Fig. 36).. 10

9. Frons narrow and deeply concave (Fig. 3); 1 psps on each side of abdominal segment III (Fig. 1); no tps on tergopleurite VI (Fig. 1); proximal mesosome roughly trapezoidal (Fig. 5) R. seminudus

-. Frons broad and shallowly concave; no psps on abdominal segment III; tps present on tergopleurite VI; proximal mesosome constricted at about midlength;

R. impressifrons

10. Lateral margins of preantennal area slightly concave (Fig. 36) or near flat (Fig. 16) in anterior half......... 11

-. Lateral margins of preantennal area clearly convex in anterior half (Fig. 10)

11. Preantennal area narrow (Fig. 36); dorsal preantennal suture reaching ads (Fig. 36); proximal mesosome flaring proximally (Fig. 38); psps present on tergopleurites IV-V (Fig. 34). $R$. extraneus

-. Preantennal area broader (Fig. 16); dorsal preantennal suture not reaching ads (Fig. 16); proximal mesosome not flaring proximally (Fig. 18); psps absent from tergopleurites IV-V (Fig. 15) R. apimimus

12. Proximal mesosome with distinct antero-lateral extensions (Figs. 24a, 31a); sinuous thickening of dorsal preantennal plate typical for genus (Fig. 22). 13

-. Proximal mesosome with at most slight antero-lateral bulges (Fig. 12); sinuous thickening of dorsal preantennal plate with distinct shape (Fig. 10) ... R. albofulvus

13. Mesosome ventrally with two distinct rugose areas on each side (Fig. 24b); marginal pmes visible as microsetae (Fig. 24a); dorsal surface of distal mesosome not rugose centrally (Fig. 23). R. longisuturalis

-. Mesosome ventrally with one distinct rugose area on each side (Fig. 31b); marginal pmes absent or not visible (Fig. 31a); dorsal surface of distal mesosome rugose centrally (Fig. 30) R. aterrimus
14. Principal post-spiracular setae absent on tergopleurite V (Fig. 9) R. albofulvus

-. Principal post-spiracular setae present on tergopleurite V (Fig. 2). 15

15. Principal post-spiracular setae absent on tergopleurite IV (Fig. 21). R. longisuturalis

-. Principal post-spiracular setae present on tergopleurite IV (Fig. 2). 16

16. Tergopleurite III with 1 ps on each side (Fig. 28).. 17

-. Tergopleurite III with no ps (Fig. 2) ..................... 18

17. Lateral margins of preantennal head slightly concave to flat in anterior third (Fig. 36) $R$. extraneus

-. Lateral margins of preantennal head clearly convex in anterior third (Fig. 29) R. aterrimus

18. Vulval margin concave in median section

R. novofacies

-. Vulval margin flat or slightly convex in median section (Fig. 7) 19

19. Frons gently rounded to slightly flattened ....R. effronte

-. Frons concave (Fig. 3) ........................................... 20

20. Tergopleurites IX $+X$ and $X I$ fused to lateral of minor seta of segment IX $+X$ (Fig. 2) 21

-. Tergopleurites IX $+\mathrm{X}$ and XI fused only median of setae of segment IX $+X$ R. impressifrons

21. Subgenital plate clearly constricted in anterior third (Fig. 7); preantennal head slender with narrow frons (Fig. 3) R. seminudus

-. Subgenital plate widening more or less evenly anteriorly (Fig. 47); preantennal head broader with flatter frons (Fig. 43) R. guangxiensis

Acknowledgements. Work was supported by grant 36/07 1.4 from the Swedish Taxonomy Initiative to DRG and SEB, grant NSF-DEB-105706 to SEB, the Introduction of Full-time High-level Talent Fund of the Guangdong Academy of Sciences grant 2018GDASCX-0809 and GIABR-GJRC201701 to DRG, and Guangdong Forestry Special Project grant 1210-1741YDZB0401 and National Natural Science Foundation of China grant 31672265 to FZ. We would like to thank Paul Brown (NHML) and Don Arnold (OSUS) for preparing loans of specimens. Karla Schneider (Zentralmagazin Naturwissenschaftlicher Sammlungen Halle/ Saale, Martin-Luther-Universität) helped us with some information about the type specimens of Mey (2017). Ricardo Palma (Museum of New Zealand te Papa Tongarewa, Wellington, New Zealand) and one anonymous reviewer provided helpful comments on this manuscript, for which we are grateful. 


\section{REFERENCES}

Alström P., Hooper D.M., LiU Y., Olsson U., Mohan D., Gelang M., Manh H.L., Zhao J., Lei F., Price T.D. 2014: Discovery of a relict lineage and monotypic family of passerine birds. Biol. Letters 10: 20131067.

ANSARI R.A.M. 1947: Mallophaga (Ischnocera) infesting birds in the Punjab (India). Proc. Natl. Inst. Sci. India 13: 253-303.

ANSARI R.A.M. 1951: Mallophaga (Amblycera) infesting birds in the Panjab (India). Proc. Natl. Inst. Sci. India 17: 127-203.

ANSARI R.A.M. 1955: Studies on the ischnoceron Mallophaga infesting birds in Pakistan. Proc. of the $7^{\text {th }}$ Pakistan Science Conference, Biology, Bahawalpur, Pakistan, 1955, Bahawalpur, pp. $42-62$.

ANSARI R.A.M. 1956: A brief survey of Bruelia [sic] species (Ischnocera: Mallophaga) parasitic on the babblers and laughing thrushes (Timaliidae). Pak. J. Hlth. 6: 133-174.

Bush S.E., Weckstein J.D., Gustafsson D.R., Allen J., DiBlasi E., Shreve S.M., Boldt R., Skeen H.R., Johnson K.P. 2016: Unlocking the black box of feather louse diversity: a molecular phylogeny of the hyper-diverse genus Brueelia. Mol. Phyl. Evol. 94: 737-751.

CiвoIs A. 2003: Mitochondrial DNA phylogeny of babblers (Timaliidae). Auk 120: 35-54.

Cibois A., Pasquet E., Schulenberg T.S. 1999: Molecular systematics of the Malagasy babblers (Passeriformes: Timaliidae) and warblers (Passeriformes: Sylviidae), based on cytochrome $b$ and 16S rRNA sequences. Mol. Phyl. Evol. 13: 581-595.

Cibois A., Slikas B., Schulenberg T.S., Pasquet E. 2001: An endemic radiation of Malagasy songbirds is revealed by mitochondrial DNA sequence data. Evolution 55: 1198-1206.

Clements J.F., Schulenberg T.S., Iliff M.J., RoberSon D., Fredericks T.A., Sullivan B.L. Wood C.L. 2017 The eBird/Clements checklist of birds of the world: v2017. www.birds.cornell.edu/clementschecklist/download/, 12/2017.

EichleR W. 1957: Notes on the Brüelia group of Mallophaga (feather-lice), with descriptions of four new species. J. Bombay Nat. Hist. Soc. 54: 577-580.

Gelang M., Cibois A., Pasquet E., Olsson U., Alström P., ERICSON P.G.P. 2008: Phylogeny of babblers (Aves, Passeriformes): major lineages, family limits and classification. Zool. Scr. 38: 225-236.

Gustafsson D.R., Bush S.E. 2017: Morphological revision of the hyperdiverse Brueelia-complex (Insecta: Phthiraptera: Ischnocera: Philopteridae) with new taxa, checklists and generic key. Zootaxa 4313: 1-443.

Gustafsson D.R., Clayton D.H., Bush S.E. 2018: Twelve new species of Priceiella (Phthiraptera: Ischnocera: Philopteridae) from Old World babblers, with keys to two subgenera and a host-parasite checklist for the genus. Zootaxa 4382: 401-449.

VON KÉLER S. 1936. Über einige Mallophagen aus Rossitten. Arb. Morph. Tax. Entomol. 3: 256-264.

Luo X., Qu Y.H., Han L.X., Li S.H., Lei F.M. 2008: A phylogenetic analysis of laughingthrushes (Timaliidae: Garrulax) and allies based on mitochondrial and nuclear DNA sequences. Zool. Scr. 38: 9-22.
Mey E. 2017: Neue Gattungen und Arten aus dem Brueelia-Komplex (Insecta, Phthiraptera, Ischnocera, Philopteridae s.1.). Rudolstädter Nat. Hist. Schr. 22: 85-215.

Moyle R.G., Andersen M.J., Oliveros C.H., Steinheimer F.D., ReDDY S. 2012: Phylogeny and biogeography of the core babblers (Aves: Timaliidae). Syst. Biol. 61: 631-651.

Moyle R.G., Filardi C.E., Smith C.E., Diamond J. 2009: Explosive Pleistocene diversification and hemispheric expansion of a "great speciator". Proc. Nat. Acad. Sci. USA 106: 1863-1868.

Najer T., Sychra O., Hung N.M., Čapek M., Podzemný P., LiterÁK I. 2012: Chewing lice (Phthiraptera: Amblycera, Ischnocera) from wild passerines (Aves: Passeriformes) in northern Vietnam, with descriptions of three new species. Zootaxa 3530: 59-73.

Najer T., Sychra O., Kounek F., Papoušek I., Hung N.M. 2014: Chewing lice (Phthiraptera: Amblycera and Ischnocera) from wild birds in southern Vietnam, with descriptions of two new species. Zootaxa 3755: 419-433.

Oliveros C.H., Reddy S., Moyle R.G. 2012: The phylogenetic position of some Philippine "babblers" spans the muscicapoid and sylvioid bird radiations. Mol. Phyl. Evol. 65: 799-804.

Pasquet E., Bourdon E., Kalyakin M.V., Cibois A. 2006: The fulvettas (Alcippe, Timaliidae, Aves): a polyphyletic group. Zool. Scr. 35: 559-566.

Price R.D., Arnold D.C., Bush S.E. 2006: Five new species of Myrsidea (Phthiraptera: Menoponidae) from Asian babblers (Passeriformes: Timaliidae). J. Kansas Entomol. Soc. 79: 369377.

Price R.D., Hellenthal R.A., Palma R.L., Johnson K.P., Clayton D.H. (Eds.) 2003: The Chewing Lice: World Checklist and Biological Overview. Illinois Natural History Survey Special Publication, Champaign, 501 pp.

RAI R.K. 1978: A new species of Myrsidea (Phthiraptera) on Garrulax (Aves) from North East India. Entomon 3: 281-285.

Reddy S., Cracraft J. 2007: Old World shrike-babblers (Pteruthius) belong with New World vireos (Vireonidae). Mol. Phyl. Evol. 44: 1352-1357.

Robin V.V., Vishnudas C.K., Gupta P., Rheindt F.E., Hooper D.M., Ramakrishnan U., Reddy S. 2017: Two new genera of songbirds represent endemic radiations from the Shola Sky Islands of the Western Ghats, India. BMC Evol. Biol. 17: 31.

TANDAN B.K. 1972: Contributions towards a revision of Myrsidea Waterston. VII. (Phthiraptera: Amblycera: Menoponidae). Bull. Brit. Mus. (Nat. Hist.) Entomol. 27: 369-410 + 2 plates.

TANDAN B.K., Clay T. 1971: Contributions towards a revision of Myrsidea Waterston. VI. (Phthiraptera, Amblycera: Menoponidae). Trans. Roy. Ent. Soc. London 123: 209-246+ 1 plate.

Waterston, J. 1915: On two new species of Mallophaga (Menoponidae): Menacanthus balfouri $\mathrm{sp} . \mathrm{n}$. and Myrsidea victrix sp. $\mathrm{n}$. from Colombia. Entomol. Month. Mag. 51: 12-16.

Yeung C.K.L., Lin R.-C., Lei F., Robson C., Hung L.M., Liang W., Zhou F., Han L., Li S.-H., Yang X. 2011: Beyond a morphological paradox: complicated phylogenetic relationships of the parrotbills (Paradoxornithidae, Aves). Mol. Phyl. Evol. 61: 192-202. 